\title{
The Idea of Women in Charlotte Bronte's Shirley
}

\author{
Ali Albashir Mohammed Al-Haj ${ }^{1}$ \\ ${ }^{1}$ Faculty of Arts \& Humanities, Department of English \& literature, Jazan University, Jazan, Kingdom of Arabia \\ Correspondence: Ali Albashir Mohammed Al-Haj, Faculty of Arts \& Humanities, Department of English \&literature, \\ Jazan University, P. O. Box 114, Jazan, Kingdom of Arabia.
}

Received: February 20, 2015

Accepted: June 7, 2016

Online Published: June 12, 2016

doi:10.5430/elr.v5n2p37

URL: http://dx.doi.org/10.5430/elr.v5n2p37

\begin{abstract}
The current study aims at studying critically the idea of women in Charlotte Bronte' Shirley .Also it aims at casting light on Charlotte Bronte as one of the most prominent female novelist in the nineteenth century. It also traces Charlotte Bronte as a subjective novelist is concerned to convey a subjective impression. Furthermore, the study provides a historical and critical background of her age in which she matured and originated the main literary tendencies which affected and swayed her and decided the expression and manner of her writings.

The study concludes, Charlotte Bronte sets up moral, spiritual and social problems such as the position of women, but evades a solution to the complications by dropping the problem and substituting the conventional solution of love and marriage.
\end{abstract}

Keywords: Charlotte Bronte Shirley, Spiritual, Subjective impression women, Love, Marriage

\section{Introduction}

Charlotte Bronte is perhaps one of the most prominent female novelist in the nineteenth century .But she is in some ways even more typical .Of course, she is not so great a novelist as Dickens; apart from anything else she had a narrower range. Her range is confined to the inner life, the private passion. Indeed, Charlotte has stood the test of time and her works are still fascinating enough to attract readers and scholars of our time despite of her narrower range. Her imagination is stimulated to create by certain aspects of man' inner life as that of Dickens or Thackeray by certain aspects of his external life. As Thackeray was the first English writer to make the novel the vehicle of a conscious criticism of life, so she is the first to make it the vehicle of personal revelation. She is the first subjective novelist (Patricia, 1992: 45), the ancestor of Proust and Mr. James Joyce and all the rest of the historians of the private consciousness. And like their her range is limited to those aspect of experience which stimulate to significance and activity the private consciousness of their various heroes and heroines.

According to Gaskell (1990: 133) :

The life of Charlotte Bronte is very substance of her novels; three times she summarized what she had imagined, seen or felt. In Jane Eyre she depicted her imaginative life; in Villette, her true moral life; in Shirley, coming out of herself a little- though very little in fact- and standing as it were at the window of her soul, she depicted the corner of Yorkshire where she lived and what little she had seen of human society.

Each of her books has therefore a very marked character in the first, Jane Eyre, Villette, the best parts of Shirley, are not exercises of the mind, but cries of the heart; not a deliberate self-diagnosis, but an involuntary self-revelation. Fundamentally, her principal characters are all the same person; and that is Charlotte Bronte. Her range is confined, not only to a direct expression of an individuals' emotions and impression, but to a direct expression of Charlotte Bronte's emotions and impressions. In this, her final limitations, we come indeed to the distinguishing fact of her character as a novelist. The world she creates is the world of her own inner life; she is her own subject.

This does not mean, of course, that she never writes about anything about her own character .She is a story-teller, and a story shows character in action, character, that is, as it appears in contact with the world of external event and personality. Only the relation of Charlotte Bronte's imagination to this world is different from that of most novelist.. In this context Gaskell (ibid,p132) points out that;

Charlotte Bronte has struck only one cord of the human heart, the most powerful it is true. In Shirley, the imagination alone speaks and when imagination is sole master one can be sure that it will run to strange, fiery passions, difficult of interpretations 
Theirs, inspired as it is by some aspect of human life outside their own, works, as it were objectively. Charlotte Bronte as a subjective novelist is concerned to convey a subjective impression. Her picture of the external world is a picture of her own reaction to the external world. But she did not write novels in order to illustrate a particular moral precept. such an obvious procedure is deliberately rejected at the end of Shirley:

I think I now see then judicious reader putting on his spectacles to look for the moral. It would be an insult to his sagacity to offer direction. I only say God speed him in the quest. (p.90).

Every page of Charlotte Bronte 's novels burns and breathes with vitality. Out of her improbabilities and her absurdities, she constructed an original vision of life; from the scattered, distorted fragments of experience which managed to penetrate her huge self- absorption, she created a world.

The present study aims at exploring the portrayal of women in Charlotte Bronte's Shirley. It also tries to give a historical and critical background of her age in which she matured and originated the main literary tendencies which affected and swayed her and decided the expression and manner of her writings which are necessary at the outset.

\section{The Traits of Victorian English Society and Charlotte Bronte's Place in it}

In order to put the selected novels of Charlotte Bronte in a social, literary and historical context, a full understanding of the cultural and social background which formed the author's instinctual make-up is necessary. So the traits of Victorian English society and the place of Charlotte Bronte in it must be examined for a grounded and more informed analysis the novel in question.

\subsection{The Social Background}

The Victorian age beginning in 187 and lasting until 1901, was a period of massive changes for England, both socially and economically. The period was generally a time of peace and prosperity and by the 1840s. England had emerged as the leading industrial society of the world and the hub of a vast colonial empire.

To quote Brownstein (2001:143)

The process of industrialization quickened as more factories were built, particularly in the north of England, heavy engineering, machine tool production and the highly mechanized cotton and wool industries powered the economic boom and attracted greater number to towns and cities

The rising middle class was amassing unprecedented wealth, but for the working population, the 1840s came to be known as the" Hungry Forties", a time of poverty and economic upheaval. While the sense of national pride at their country's exalted position on the world stage may have been gratifying to the British people, what mattered most to them was the quality of their lives at home. The process of social development and political reform which had begun earlier in the century continued throughout the Victorian period.

The Victorian period was an age with new activities. There was a revolution in commercial enterprise, due to great increase of available markets, and, as a result of this, an immense advance in this use of mechanical devices. The new commercial energy was reflected in the Great Exhibition of 1851.

According to Brownstein (ibid,p,143):

The Great Exhibition, which opened in London in the newly constructed Crystal Palace on the first of May 1851, was a highpoint in the history of Victorian Britain,. The industrial and artistic achievement of the nation were put on display for the world to admire.

While millions did admire, others pointed out that, despite as seemingly endless success story. Britain was far from being a paradise on earth, Much criticism focused on the squalor and deprivation that was still to be found in the cities. While the middle and upper classes gloried in the prosperity of the times, the far-growing industrial working class began to question the premise that each such prosperity necessarily involved demeaning and exploitative working conditions and undemocratic political representation.

Billington(1988:120) mentions that there was also the question of the growing number of poor, unmarried" surplus" women, who had limited means of supporting themselves and who were beginning to pose a real problem to society. One of the few options for the unmarried surplus women, who needed to support themselves, was to become a governess. A governess was one of those people without position in society because she did not belong to the household or the servant. It was a bitter experience shared by many women including Charlotte Bronte herself.

The occupation of governess has special appeal for middle-class women during the Victorian era. At this period, a woman who was not finically supported by a husband or other male relative had few days to earn a living. While many women in 1800s did work in mills and factories, the unmarried daughters of merchants, doctors, lawyers, and 
clergymen sought more" suitable" employment that could offer a moderately respectable lifestyle. A governess lived with the upper-middle class or upper-class family who hired her to teach their children. In addition to securing comfortable lodgings, she earned a modest salary.

During the Victorian period took a similar stance toward the position of women especially working women. The subject of work for women was particularly relevant for women writers, who experienced personal conflicts as a result of their desire to be viewed both as domestic and womanly and of their needs as artists to assert themselves in the performance of work. Charlotte Bronte focuses on their conflict in the partly autobiographical Jane Eyre (1847). After Jane leaves Mr. Rochester, she is forced to seek work. Because she is a woman, only a limited number of options are available to her. She tells St. John Rivers:

I will be a dressmaker; I will be a plain-workwoman; I will be a servant, a nurse-girl, if I can be no better.( Bronte, Jane Eyre,p,375)

When she is offered the post of village schoolmistress, she accepts, realizing that it is the best among several unsatisfactory choices. However such work- though somewhat socially acceptable since she has no one to support her- is not fulfilling for the unmarried Jane; after a "day passed in honorable exertion" (J.E. ibid, p,256.).She experiences strange dream at night: dreams many-colored, agitated, full of the ideal, the stirring, the stormy." (J.E, ibid,p,156). The kind of work that is accessible to Jane does not give full play to her talents and faculties

Likewise, in Bronte's Villette (1853),Lucy Snowe, faced with the necessity of supporting herself, resolves to become a governess, taking the attitude "I had to lose"(Brone,Villette,p,57). For Lucy," work had neither charm for her(her) taste, nor hold on her interest "(Villette, ibid, p,.78).Like, Jane she earns for stimulus:" I did long, achingly,... for something to fetch me out of my present existence, and lead me upwards and onwards."(V, ibid ,p 90) in both cases, what the woman desire-scope for their abilities - is not socially acceptable for them to pursue. For Bronte, womanly and artistic duties were perpetually in conflict. For her characters, work, in the sense of an activity that earns daily bread, is at odds with vocation, an inclination or calling that brings intellectual and emotional gratification. Bronte's novels emphasize the waste of female potential.

Hunt(1988:12) observes that:

Throughout the eighteenth and nineteenth century, along with the debate on women's position in society, there co-existed a unanimity on what is natural to the female character.

According to the Victorian ideal, woman was the " angel in the house" and she was expected to be submissive, chaste, and physically frail, in addition to being religious, self-denying and capable of tremendous feats of self- discipline . Armed with these contradicting characteristics, the Victorian women were seen to represent morality and strength against, harsh and competitive world of business, in which men could not afford to possess.

Besides the social tension that existed in the Victorian society, there were also disagreements about what the core values of society should be. Not everyone accepted that increased material wealth was the only worthwhile value . Writers like Mathew Arnold represented the views of those who felt that over-emphasis on materialism was turning nineteenth- century Britain into a less caring society, where cultural and artistic pursuits were looked on as distractions from the main objective of making money.

\subsection{The Literal Background}

As the Renaissance is identified with drama and Romanticism with poetry, the Victorian age with the novel. There are several reasons for the triumph of fiction, but perhaps the most significant is the rapid growth in the middle classes who, since the eighteenth century, had been avid consumers of this form of literature. Other factors, such as an improved education system, which led to grater literacy, and a fall in book prices, due to improved printing techniques and cheaper transport costs, also contributed to the success of the novel. Circulating libraries became very popular and allowed people to borrow books for a relatively modest sum. Women, who had been freed from traditional chores such as candle and bread making, had more time to dedicate to reading and became avid consumers of fiction. Indeed, the Victorian age is characterized by the emergence of women not just readers but also as influential writers.

By the middle of the nineteenth century the novel, as a species of literature, bad thrust itself into the first rank. We shall therefore consider it first. In the novels of Thackeray and Dickens the various qualities of the domestic novel are gathered together and carried a stage forward. Dickens was a social reformer, and yet did much to realize the England of his day, and to depict the life of the lower and middle classes with imagination and humor. With the Bronte sisters the romantic impulse was fully felt in the novel, to which they gave new intensity of passion, greater 
depth of intuitive sympathy, and a profound interest in the struggles of the individual soul. In this they were followed by George Eliot, who showed a closeness of application to the mental processes of her characters that was carried further in the work of Meredith, and has led to the "psychological ' novel of the present day. Most of George Eliot's novels are set in the Warwickshire countryside of her childhood, against which underlines the importance of love and family, Eliot hits at Victorian materialism. The same theme recurs in her novel Middlemarch (1871- 1882), in which she describes life in a provincial town in 1832. Readers in the 1870s could see how much progress had been made in medicine, transport and commerce, while at the same witnessing how little progress had been made in social concern for the foreshadows later Victorian writers in her rejection of the prevailing moral and religious code of the society in which she lived. Her exploration of the psychological analysis which was to dominate much of twentieth - century fiction.

George Eliot also dealt more interestingly with history in her rural idyll Silas Marner (1861) than in her major historical novel Romola (1862-3).Marner tells how Silas escapes from the harsh industrial world of Lantern Yard into the Arcadian village of Raveloe. He buries his treasured guineas, lumber from his urban past, under the floor of his hut. When they are stolen, they become replaced in the gloom by the gleaming locks of the baby Eppie, ringlets which Silas' weak eyes firstly believe to be his returned gold. It is Christmas, and the parable of redemption through the coming of a child rings clear. But Sally Shuttle worth has suggested that, beneath the symbolism, the story explores current views of social development. The innocence of the rural Raveloe community is undercut by the villagers' inability to see that 'they are pressed hard by primitive wants', and exploited by the feudal squirearchy of the Red House (ch. 6). Silas' past is both his weakness and his strength. If his soul has been withered by his life in Lantern Yard, the hardness of industrial living has created the sturdy independence that leads him to adopt and rear the child Eppie in durance of village advice. Silas has been physically stunted by labor at the loom, yet in a (literally) touching scene, when Jane and Godfrey Cass come to reclaim Eppie, Eppie can comfort and strengthen Silas because she knows the history of his weaver's hands, and understands that his craft has made them unusually responsive to her touch. 'She held Silas' hand in hers, and grasped it firmly - it was a weaver's hand, with palm and fingertips that were sensitive to such pressure' (ch. 19). By means of a human touch, history becomes alive in the domestic present.

The most famous representation of madness in Victorian literature is Bertha Mason in Charlotte Bronte's Jane Eyre. While Bertha in Jane Eyre is depicted as mad before she is portrayed as an arsonist, she represents a prototype against which the depiction of mad women in Victorian novels may be measured. Furthermore, while she is not initially depicted as criminal, the issues of foreignness, miscegenation, class, and hereditary taint come into play in her characterization.

In Felix Holt (1866) George Elliot comes closest to making a female character the center of her novel in her portrait of the daughter of a dissenting minister, Esther Lyon.( Rogers:1985:92). Eliot is interested in tracing the spiritual journey of a young woman whose understanding is deepened when she is exposed to attitudes and values that are very different from her own. Like many of Caskell's characters, Esther is intellectually lively, yet unlike Gaskell's characters, at the beginning she is morally immature. With her refined tastes, she delights most in her own creature comforts, spending her wages on wax (not tallow) candles, attar of rose, collections of Byron's poetry. Though her relationship to a young radical. Felix Holt, Esther becomes aware of the possibility of a nobler life, one that is not found upon the satisfaction of purely personal desires, but dedicated to an idea, a hope that the condition of the working calls can be improved.

\section{Charlotte Bronte's Contribution, Reputation and Influence}

\subsection{Charlotte 's Life: Family Background}

Charlotte and family Bronte were born in the small isolated village of Haworth on the Yorkshire moors where they lived with their father, who was the local vicar, their mother, three sisters and a brother.

According to Alexander(2001:9)

Charlotte Bronte, born in 1816, grew up in the small mill town of Haworth on the edge of the rugged of West Yorkshire, in northern England. The setting was isolated and made lonelier by the fact that charlotte's mother had when Charlotte was five. Charlotte, her four sister-Maria, Elizabeth, Emily and Anne and their brother, Barnwell, turned to each other for companionship.

Due to the harsh conditions in the orphanage two sisters fell ill and consequently their father brought all five of them back to the family home. Charlotte Bronte was avid reader of Shakespeare, Milton, Byron, Scott, the Classics and the Bible. Furthermore, she showed an early gift for writing, and as a form of amusement she wrote miniature books about fantasy worlds of her own creation with the help of her sisters as Gordon(1994:45) points out: 
Throughout their childhood and into adulthood, the close-knit Bronte children entertained themselves by creating fanciful stories. Inspired by a set of twelve wooden soldiers their father brought home, they invented imaginary worlds that were a blend of myth, history, current events and society-pages stories from newspapers and magazines.

Gradually Charlotte Bronte came to focus on romantic passion and themes of temptation and betrayal in these melodramatic tales. This story-writing provide an essential outlet for her creativity, an outlet she would painfully miss once she began her "wretched bondage". In 1855, after just a few months of married life, Charlotte Bronte die due to complications associated with pregnancy. Her final words to friends in her letter confirm her deeply bond with her husband:

I find my husband the tenderest nurse, the kindest support - the best earthly comfort that any women had... as to my husband-my heat is knit to him.

(Gordon 1994: 425).

\subsection{Charlotte's Contribution, Reputation \& Influence}

Charlotte Bronte admits the restrictions imposed upon women writers yet denies her suffering from them, or at least their hindering influence on her. At the same time, she denies the masculine gender of the pen name with which she signed her works and insists on its general neutrality. She can debate the gender of the name, but fails to offer an explanation why she, if she is such a daring woman, dares not write under her original name. Charlotte Bronte was more introvert by her nature and in her writing because of the partly voluntary seclusion of her family and also of the romantic era, which affected the cultural atmosphere of the time by emphasizing the exploration of nature and emotion.

Charlotte was much more in the world than her other contemporary writers, and her increasing contact with it on a variety of planets is revealed in her interest such as charity schools and their abuses, and the position of governess and teachers, is the work still of an individual not aware of herself or of these issues as part of a wider society. Hence it is the individual and isolated passion of Jane that is central ; her anger at injustice, her temptation to forget the world and religion for individual happiness, her seeking for a fit and independent mode of existence. The Universe of Jane Eyre approaches that of Wuthering Height in the exploring of an individual's reaction to its own moral ambience and emotional universe. But this was not solely Charlotte's sphere for she was not the isolated spirit family was. The position of women, the fear of being an old maid, the struggle for independence on the world's terms, not by retreat to the spiritual, make Shirley and Villette novels based more firmly in a recognized society. They deal with problems of the individual seen more and more in relation to society, while still revealing an individual vision.

Charlotte Bronte's writing is a powerful agent in her effect. The scenes in her novels, indeed, are the peak of Charlotte Bronte's achievements; for in them, as in no others, her imagination finds the perfect fields for its expression. Her pictures of love and character, though they reveal her powers, and it offers equal scope to her intensity and more on her she cannot satisfy. No power of psychological penetration or accurate observation in needed to communicate the impression of the senses in an abnormal nervous state; while to be dreamlike and unrestrained is characteristic of such impressions. For once Charlotte Bronte is true not only to imagination, but to fact.

Charlotte Bronte was a genius. She had, that is, that creative imagination which is the distinguishing quality of the artist, in the very highest intensity. In spite of the frustration that the women probably felt as surplus women, Charlotte had very realistic attitudes towards marriage for herself and she decided that mere respect without affection was not enough, although marriage would have made them independent from the charity of others. In Charlotte's work she relied on the same principle and married their heroines to men they loved but also sure that happy couples were well off. However, Charlotte, in later life gave up her principle by marrying Mr. Nicholls, a man she respected but was not sure if she would love.

Naturally Charlotte was too much of a Victorian and too much of a Puritan to do more than hint at its animal side. But her hints are quite enough to prevent the emotion seeming disembodied and unreal. Even Caroline Helstone, that blameless dummy, comes to life when alone in her room she abandons herself to her yearning for Robert Moore. Here is a frustrated love. And writing as she does of the emotion of her own unsatisfied heart, Charlotte Bronte is most characteristically concerned to describe a frustrated love: Jane Eyre's love for Rochester, so hopelessly, as it would seem, out of her reach; Lucy Snowe's for Dr. John, absorbed already in Ginevra Fanshawe. But the fact that it is frustrated does not make the love of Charlotte Bronte's heroines less intense. Indeed it makes it more of an obsession. Moreover, Charlotte Bronte can describe happy love equally well, if her story gives her a chance, As a 
matter of fact love is the occasion of her few successful flights of humor. Jane Eyre teasing Rochseter, Lucy Snowe sparring with Paul Emanuel, in these she achieves real comedy. It is a little stiff shy; it is also enchantingly demure and delicate; a sort of Puritan comedy of the sexes, unlike anything else in English literature. In addition to love' gaieties she can describe love's ecstasy.

Like most of the other novelist of her school, Charlotte Bronte is a poet; and her poetry is the pure lyrical poetry of passion. It connects itself with her sensibility to landscape. The special emotion of her love-scenes swells to assimilate to itself the emotional quality of the scenery amid which they take place. In language of stilted compliment Mr. Rochester converse with Jae Eyre in his garden, and then he says " listen to the nightingales,". ( J.Y.123). And the four simple words, like the note of a violin, quicken the scene to a lyric rhapsody, in which the scent of the jasmine flowers, the chestnut in the distant sky, join to convey and symbolize the passion that animate the two beings who move among them. In this sort of effect she has no predecessor in English, and no successors till Meredith.

\section{The Portrayal of Women in Shirley}

At first glance, Shirley appears to have no relationship to Charlotte Bronte's other novels: it seems to be an attempt at another genre, an experiment she did not repeat. Although she was to tell Mr. Smith(2000:68)

I cannot write books handling the topics of the day; it is of no use trying. Nor can I write a book for its moral. Nor can I take up a philanthropic scheme.

Shirley is, nevertheless, a departure in this direction, being a historical, provincial and social novel that focuses on English middle-class women especially single women victimized in contemporary society. In a letter to W.S William written during the planning of Shirley. Charlotte Bronte expresses her wish for' the better ordering of the Social System':

I often wish to say something about the' condition of women's questions- but it is one respecting which so much 'cant' has been talked, that one feels a sort of repugnance to approach it. It is true enough that the present a market for female labor is quite overstocked- but where or how could another be opened?....

\subsection{The Story of the Novel}

The plot is a complicate one, since it consists of a number of parallel stories. Although the novel takes its title from one of the characters, that character cannot be said to be the sole protagonist. The novel begins with a not very flattering picture of the curates of the area, and an attack on the new machinery for the mill. It ends in the Victorian welter of marriages and reconciliations. Caroline Helstone's parents separated soon after her birth and she lives with her uncle, the Reverned Helstone, rector of Briar -field. She is in love with Robert Moore, who is of Flemish and English extraction, and whose father was distantly related to Caroline's mother. Robert's whole concern in life is the success of Hollow's - mill and he is determined to install machinery there to ensure this success. Early in the story an argument between Helstone and Moore results in Caroline being forbidden to visit Hollow's cottage, though even before this she has come to doubt Robert's love for her.

Miss Shirley Keeledar, heiress, landowner in the district and landlord of the mill, arrive with her governess, Mrs. Pryor, to stay for a while at her house, Fieldhead, since she has come of age. A strong friendship springs up between the two girls. Together they witness the attempt by the workers on Hollow's mill, together they take walks, together they take part in the annual Sunday-school walk and tea-drinking.

Caroline falls into a decline, and is nursed to health by Mrs. Pryor, who turns out to be her long-lost mother. Shirley is visited by her uncle, Mr. Sympson, his family and his son' tutor. Moore who wants to marry her for her fortune, Shirley at length confess to her love for the tutor, Louis Moore, brother of Robert, whom she has loved since she lived with the Sympson family as a girl . Robert Moore, shot by a leader of the workman, is nursed to health by his friends, The Yorkers, repents his general harshness, and marries Caroline.

Charlotte Bronte ends the story with the following;

The story is told. I think I now see the judicious reader putting on his spectacles to look for the moral. It would be an insult to his sagacity to offer directions. I only say, God speed him in the quest!'( Shirley, 646).

Despite the obvious irony of the above-mentioned passage- in its reference to a male reader in particular, really, there is a 'moral' in Charlotte Bronte's Shirley, especially for the woman reader The 'moral' that comes to the fore in my reading of Shirley would seem to be the contemporary society depicted in the novel does not yet allow women to be full liberated and the social equals of men. Shirley is corrected by her ' mirror image', and shown the proper behavioral patens for young women in the early nineteenth century. 
However carefully in Charlotte Bronte limits the area of story in time and place, however carefully she marks political, social and religious influences, the novel is not of the Victorian social reform kind. There is no reforming zeal at work. The brief picture of the child laborers coming to the mill evokes no Dickensian indignation ; the poverty-off workers no Gaskellian pity.

To quote Argyle( 1995:741):

Shirley presents a notable contrast to Miss Bronte's other novels... The world of toil and suffering lies behind, but ever so far away. True, it must be again encountered, its problems resolved, its sores probed; the hard and obstinate war again waged manfully; but in the mean time the burn foams and sparkles through the glen; there is sunshine among the purple harebells; and the leaves in the birken glad dance merrily in the summer wind.

\subsection{Shirley and Idea of Women}

Through the novel, Charlotte Bronte shows how the patterns of women's lives( and those of the workers) are shaped by social attitudes and forces over which they have no control. That the woman question is one of the main theme of the novel is recognized by both readers and the critics of the time.

Although a concern with the position of women in society and the kinds of lives they lead is implicit in her other novel, it is only in Shirley that it becomes a predominant theme centering on the lives of the two heroines Caroline and Shirley. On this context we can quote Bellringer(1993: 122):

In Shirley, Charlotte Bronte is also concerned with the opposition between the more general behavior of both protagonists, and she links this with the contrast between the opposite traits of passionate feeling and excitement, of individual freedom and fulfillment, and those of self-transcending or self-denying duty and moral responsibility. Rather than presenting this kind of divided approach in one character, as she does in Jane Eyre, she splits the behavior into two parts, assigning that the timid and dutiful young girl to Caroline, and that of the tougher and more independent women to Shirley.

Caroline's lack of character, her long, brooding inactivity in the novel, her seriousness, are as much the result of the weariness of life without purpose of an unmarried woman as of the sorrowing and decline of the girl crossed in love. Shirley is, of course, is shown to have much to occupy her, but even so, a comparison of the occupations. Shirley's pursuits are quite as trivial in some ways as those of Caroline. Fundamentally, it is Shirley's nature which enables her to find such restrictions of activity not irksome.

In the novel, Caroline, is portrayed as shy. Her timidity is illustrated by Yoke's comparison of her pale quietness to one of the marbles of Canova (Shirely,539). She is, Shirley tells Moore, quite feminine "nor of what they call the spirited order of women"(Shirely,363), a girl whose rare outbursts have no" manly fire", but only " a short, vivid, trembling glow, that shot up, shone, vanished" and almost" left her scared at her own daring" (Shirely,364). Yet, at the same time, as Shirley also points out, Caroline" though gentle, tractable, and candid enough, is still perfectly capable of defying even Mr. Moore's penetration"(Shirely,364).

In the novel also, Shirley is portrayed as an intelligent woman, observes men' treatment of women and recognizes the perception that underline it. When Robert Moore does not inform her of the attack on the mill, even though he owns it, she marks that men tell women nothing and keeping them completely in the dark about subjects which involve danger. She comes to the conclusion that they perceive women to have as much capacity for thought as children, and clearly that she think this wrong:

In any case, Charlotte Bronte offers no solution to the feminist problem in this novel. Shirley, the landowner, farmer, mill owner and heiress, abdicates wealth, position and power in favor of her husband; Caroline marries Robert Moore and the problems of unmarried life are removed from her. But a third attitude to the feminine dilemma is suggested by the young girl, Rose Yorke, in her determination to use the talents God gave her and bury them in a life of domesticity.

\section{Conclusion}

Love, indeed, is the central theme of Charlotte Bronte's novels: for it was inevitably the main preoccupation of so passionate a temperament. Her power to describe it is of course, conditioned by the nature of her genius. She cannot dissect the workings of passion, nor can she illuminate its effect on character. What she can do is to convey its actual present throb. And this she does as it had never been done before in English fiction.

Finding love and getting married seem to be two of the most important themes in Charlotte Bronte's Shirley. The novel is filled with unhappy marriages- marriages in which it is the woman who comes off worst- and this is closely related to the feminine theme, both involving a man's view of woman. 
In Shirley, the men generally are unwilling to accept women as equal and intelligent partners. A woman like Shirley is looked upon as a good match because of her money, Helstone prefers women who are light-headed so he can see them at his inferiors .His wife pined away almost unnoticed-he believes that people tire of one another in marriage. Mrs. Pryor comments:

... life is an illusion... most of the cheats of existence are strong.... [ the] sweetness [of love] is... transitory( Shirely,364).

Shirley gives her opinion as to how one may judge the right mate, by observing his behavior with others, with those weaker and more helpless than himself, by observing his attitude to women. But this a minority view in face of all the opinions raised against marriage in the novel.

Set against the men are the women, seen as old maids, young girls with their sights set on marriage, housewives, either married or single. Of these, the latter are in some ways most content- Mrs. Yorke and Hortense Moore have their household duties to occupy them. Miss Mann and Miss Ainley find their satisfaction in good works of a charitable kind, but under the dominance of male direction Young girls lead idle existences hoping to marry eventually.

Shirley is an attempt on a woman's part to straddle the two groupings. She is a woman who, through birth and position, occupies many of the posts normally filled by men; she refers to herself as Captain Keeldar. But it is noticeable that she is a figure-head in her position as landowner. She has more authority, more intimacy with business concerns than Caroline, but at crucial moments in political events she must retain the passive role of a woman.

Shirley is intended to have greater insight into what is going on than everyone else, but since she does not reveal her insights until a situation has been revealed to her, she is unconvincing. The attempt to portray the Charlotte- heroine in fortunate circumstances as well as the attempt to analyze the situation of the unmarried woman is unsuccessful because both, by their nature, are dogged by lack of appropriate action.

Finally, Charlotte Bronte's picture of love and marriage reveal her power. But solitary obsession, while it offers equal scope to her intensity and more to her imaginative strangeness, makes no demands on her she cannot satisfy. No power of psychological penetration or accurate observation is needed to communicate the impressions of the senses in an abnormal nervous state; while to be dreamlike and unrestrained is characteristic of such impressions.

\section{References}

Alexander, Sally. (2001). Women's Work in Nineteenth Century London: A Study of the Years 1820-1850. London: Journeyman.

Argyle, Gisela. (1995). Gender and Generic Mixing in Charlotte Bronte's Shirley. Studying in English Literature 1500-1900.35.4(1995), 741-756)

Bellringer, Alan W. (1993). Charlotte Bronte 's Shirley: A casebook. London: Macmillan.

Billington, Rosmund. (1988). The life of Charlotte Bronte. London: Macmillan.

Bronte, Charlotte. (2003). Shierly. London: Penguin. 